Vol. 1 No. 2 (2018)

\title{
DILEMA ALIANSI AMERIKA SERIKAT TERKAIT PENINGKATAN KAPABILITAS MILITER JEPANG
}

\author{
Meidy Amanda \\ Departemen Ilmu Hubungan Internasional, Universitas Indonesia \\ meidyamanda@ymail.com
}

\begin{abstract}
This paper examine the enhancement of military alliance between Japan and Unites States under Japan constitution. After the World War 2, Japan's loss left Japan without enough defense to protect its country. Under the San Francisco Agreement, the United States and Japan make a Security Cooperation. With all the dynamics on the International Relation, United States and Japan have enhance their security alliance. This research will use alliance dilemma theory by Glenn H. Snyder. According to Snyder when the alliance is formed, the state has two choices in its alliance, cooperate or defect. The risk is when a state decided to make an alliance, the state will entrapped on the alliance. While if a state decided to defect, the state will get abandonment. So, this paper will examine the decision of the United States. In this case, enhancement of the security cooperation between United States and Japan is caused by alliance dilemma that make United States does not want to be entrapped into a regional conflict over an ally which is Japan.
\end{abstract}

Keywords: Alliance dilemma, United States, Japan

\begin{abstract}
Abstrak
Tulisan ini membahas peningkatan aliansi militer Jepang dengan Amerika Serikat di bawah batasan konstitusi Jepang. Setelah Perang Dunia ke-2, kekalahan Jepang membuat Jepang tidak memiliki pertahanan yang cukup untuk melindungi negaranya. Di bawah Perjanjian San Fransisco, Amerika Serikat melakukan kerja sama keamanan dengan Jepang. Dengan segala dinamika konflik hubungan internasional yang ada, Amerika Serikat dan Jepang meningkatkan aliansi keamanannya. Penelitian ini akan menggunakan teori dilema aliansi oleh Glenn H. Snyder, menurut Snyder ketika aliansi terbentuk, negara memiliki dua pilihan dalam aliansinya yaitu melakukan kerja sama (cooperate) atau membelot (defect). Resikonya adalah ketika negara memilih untuk bekerja sama, negara akan terjebak (entrapped) dalam aliansi tersebut, sedangkan apabila sebuah negara memilih untuk membelot, maka negara akan ditinggalkan (abandonment). Oleh karena itu, makalah ini akan membahas bagaimana keputusan Amerika Serikat dalam aliansi tersebut. Dalam hal ini, peningkatan kerja sama keamanan antara Amerika Serikat dengan Jepang disebabkan oleh dilema dalam aliansi yang menyebabkan Amerika Serikat dalam posisi tidak ingin terjebak (entrapped) ke dalam konflik regional yang melibatkan mitra aliansinya yaitu Jepang.
\end{abstract}

Kata kunci: Dilema Aliansi, Amerika Serikat, Jepang 
Vol. 1 No. 2 (2018)

\section{Pendahuluan}

Teori-teori dalam ilmu hubungan internasional sudah banyak menganalisa hubungan internasional mulai dari hubungan ekonomi, sosial, politik, maupun budaya. Namun setiap negara pada dasarnya menginginkan kepentingan nasionalnya tercapai dalam hubungan internasional. Kepentingan-kepentingan nasional itu seperti kesejahteraan, keamanan dan kekuatan untuk negaranya sendiri. Seperti pendapat yang disampaikan Mearsheimer, sistem internasional bersifat anarki, sedangkan terdapat tiga sifat negara yaitu adanya rasa takut, pertolongan terhadap diri sendiri (self-help) dan maksimalisai kekuatan (Mearsheimer, 2001).

Ketika sebuah negara memaksimalkan kekuatannya, negara akan merasa terancam atau yang disebut juga dengan security dilemma. Menurut Glenn H. Snyder, teori tentang security dilemma menjelaskan walaupun tidak ada negara yang memiliki keinginan untuk menyerang negara lain, tidak ada yang bisa yakin bahwa niat negara tersebut adalah untuk perdamaian, sehingga negara lain harus mengakumulasi kekuatan untuk pertahanan.

Pada masa Perang Dunia II, Jepang merupakan negara yang cukup kuat dan agresif dalam sistem pertahanannya. Salah satu invasi Jepang yang dikenal dengan kekejamannya adalah tragedi Nanking, Tiongkok yang menyebabkan Jepang menjadi perhatian internasional, terutama Amerika Serikat. Sanksi embargo ekonomi Amerika Serikat terhadap Jepang pada saat itu melemahkan kekuatan militer Jepang. Tidak berdiam diri, Jepang melebarkan invasinya ke negara-negara di Asia Tenggara seperti Vietnam dan Indonesia. Namun, embargo yang dilakukan Amerika Serikat tetap menjadi hambatan bagi Jepang. Hingga Jepang melakukan penyerangan terhadap pangkalan militer Pearl Harbor milik Amerika Serikat di Hawaii. Kemudian Amerika Serikat melakukan serangan balasan dengan meluncurkan dua bom atom "Little Boy" dan "Fat Man" ke Hiroshima dan Nagasaki yang menyebabkan Jepang mengakui kekalahannya dan melakukan penyerahan diri terhadap Amerika Serikat dan Sekutu.

Setelah kekalahan Jepang pada Perang Dunia II, sistem pertahanan militer Jepang dibatasi oleh pasal 9 konstitusi 1947. Sejak itu, Jepang hanya memiliki Self-Defense Forces yang seluruh pasukannya merupakan warga sipil. Pasukan keamanan tersebut juga hanya boleh beroperasi di dalam wilayah teritori Jepang dan juga bergerak dalam misi-misi perdamaian dengan PBB. Hal ini menyebabkan sifat pertahanan Jepang yang pasifis. Kemudian dilanjutkan dengan Perjanjian San Fransisco tahun 1951 sebagai upaya dalam menjaga komitmen perdamaian. Perjanjian San Francisco dianggap menjadi cikal bakal aliansi pertahanan antara Amerika Serikat dan Jepang. Dari pembentukan USJapanese Security Treaty kerja sama keamanan Amerika Serikat dan Jepang dimulai. Namun perjanjian keamanan tersebut tetap membatasi gerak pertahanan Jepang. Sifat pertahanan Jepang hanya sebatas pertahanan (defensif) dan bukan untuk penyerangan (offensive). Amerika Serikat juga menyatakan untuk ikut serta dalam 
membantu melindungi keamanan Jepang dari serangan dan ancaman pihak luar. Skema kerja sama keamanan Jepang dan Amerika Serikat tersebut diatur dalam Japan-US Defense Guidelines.

Seiring dengan berjalannya waktu, teknologi dan perekonomian Jepang yang semakin maju membuat Jepang memulai kembali meningkatkan pertahanannya. Dalam perkembangannya, AS justru mendorong Jepang untuk mengembalikan kekuatan militer Jepang. Berawal dari Perang Korea dimana fokus militer AS diarahkan kepada Semenanjung Korea. Bahkan, Amerika Serikat ikut membantu Jepang dengan melakukan latihan militer gabungan dengan Amerika Serikat. Pada tahun 2017, Jepang melakukan latihan militer besar-besaran di darat, laut dan udara. Latihan perang angkatan laut gabungan melibatkan 14.000 tentara AS, kapal induk USS Ronald Reagan dan tiga kapal perang (USS Stethem, USS Chafee dan USS Mustin) di Okinawa (Muhaimin, 2017). Pasukan Pertahanan Udara Jepang (ASDF) juga melakukan latihan gabungan dengan melibatkan dua pesawat pengebom B-1B milik Angkatan Udara AS, dan dua jet tempur F-2 (CNN, 2007). Jepang juga akan membeli rudal jelajah jarak jauh milik Amerika Serikat dan akan terus meningkatkan kapabilitas pertahanannya dengan dukungan Amerika Serikat dan Sekutu. Dengan hadirnya China sebagai kekuatan baru di kawasan, AS semakin berkepentingan untuk mendorong peningkatan kapabilitas militer Jepang. Meskipun Amerika Serikat terlihat mendukung perkembangan Jepang, dari sudut pandang aliansi hal ini menunjukkan perilaku defecting karena Amerika
Serikat tidak sepenuhnya menjadi "pelindung" keamanan Jepang lagi. Sehingga, dilihat dari upaya Jepang dalam peningkatan kapabilitas pertahanannya, dapat dikatakan bahwa saat ini Jepang dilatih untuk berperang dan sifat kebijakan keamanan Jepang tidak lagi pasif, tetapi aktif dan offensive yang dapat melanggar pasal 9 konstitusi 1947. Namun, penyebab Amerika Serikat ikut meningkatkan kapabilitas pertahanan Jepang tersebut belum banyak dikaji dalam kajian-kajian terdahulu aliansi Amerika Serikat dengan Jepang.

Kajian terdahulu tentang aliansi militer Amerika Serikat dan Jepang umumnya melihat tiga isu besar, yaitu (1) Kepentingan kedua negara untuk melakukan aliansi, (2) Bentuk-bentuk kerja sama politik ekonomi Amerika Serikat dan Jepang, (3) Persepsi ancaman dari Amerika Serikat dan Jepang yang menjadi alasan Amerika Serikat melakukan aliansi dengan Jepang. Kajian pertama yaitu tentang adanya kepentingan nasional dari masing-masing negara ketika melakukan aliansi (Manthai, 2000; Mulgan, 2010; Mathur, 2007; Kim, 2011; Kelly, 2014)) menjelaskan bahwa kedua negara melakukan aliansi atas dasar kepentingan nasionalnya. Amerika Serikat melakukan aliansi dengan Jepang untuk menjalankan strategi global AS, bahkan dikatakan juga AS ingin menjadi hegemoni di Asia Timur dengan aliansi tersebut. Sedangkan kepentingan Jepang terhadap AS adalah untuk mendapatkan perlindungan keamanan atau yang disebut juga "payung" nuklir AS.

Kategori kajian yang kedua adalah kerja sama politik ekonomi yang dilakukan Amerika Serikat dan Jepang 
Vol. 1 No. 2 (2018)

(Ando, 2013; Menenberg, 2014; Chull, 2017; Hughes, 2007) menjelaskan bahwa kerja sama antara Amerika Serikat dan Jepang terdapat dalam beberapa bidang seperti pendidikan, ekonomi dan pertahanan. Jepang juga bukanlah free rider karena Jepang juga memiliki sistem perekonomian yang maju sehingga dapat membantu Amerika Serikat dalam kegiatan kerja samanya. Disebutkan pula, aliansi Amerika Serikat dan Jepang juga membawa perubahan terhadap kebijakan luar negeri Jepang. Kategori kajian yang terakhir adalah persepsi ancaman yang dirasakan Amerika Serikat dan Jepang (Ito, 2004; Wirth, 2015; Wook, 2015; Wetson, 2014) menjelaskan bahwa setelah berakhirnya Perang Dingin, terdapat persepsi ancaman bagi Amerika Serikat-Jepang yang berasal dari kebangkitan Tiongkok dan pengembangan nuklir Korea Utara.

Ketiga kategori kajian terdahulu tersebut telah menunjukkan aliansi Amerika Serikat dengan Jepang dari alasan mereka melakukan aliansi, bentukbentuk kerja sama Amerika SerikatJepang, dan persepsi ancaman yang dihadapi kedua negara tersebut. Ketiga kajian tersebut, belum mampu menjelaskan alasan peningkatan aliansi Amerika Serikat dan Jepang dalam bidang pertahanan. Di sisi lain sistem pertahanan Jepang sudah dibatasi oleh konstitusi yang menjadikan Jepang sebagai negara yang damai dan anti perang. Berdasarkan hal tersebut, tulisan ini berpendapat diperlukan kajian yang dapat menjelaskan alasan Amerika Serikat melakukan peningkatan kerja sama keamanan dengan Jepang meskipun sudah dibawah batasan konstitusi Jepang dan sanksi internasional. Untuk itu, tulisan ini menggunakan teori dilema aliansi untuk menjelaskan sikap Amerika Serikat dalam meningkatkan sistem pertahanan Jepang. Oleh sebab itu, tulisan ini menjelaskan operasionalisasi teori dilema aliansi dalam sikap Amerika Serikat yang menjelaskan Amerika Serikat mengalami dilema seiring dengan munculnya berbagai isu kemanan di kawasan sehingga ikut meningkatkan sistem pertahanan Jepang. Di bagian berikutnya, secara berurutan tulisan ini menjelaskan mengenai teori dilema aliansi, pembahasan yang berisi analisa alasan Amerika Serikat melakukan kerja sama untuk meningkatkan pertahanan Jepang dari sudut pandang teori dilema aliansi, dan bagian penutup.

\section{Metode Penelitian Dilema Aliansi}

Sydner menjelaskan security dilemma dalam alliance game terdapat dalam dua fase: utama dan kedua. Fase utama terjadi selama proses formasi aliansi, fase kedua yaitu setelah aliansi terbentuk. Menurut Snyder, setiap negara memiliki dua pilihan yaitu membentuk aliansi atau menjauhkan diri (abstain). Bagaimanapun juga, aliansi akan terbentuk karena dua alasan. Pertama, beberapa negara mungkin tidak puas dengan keamanan moderat, dan mereka dapat meningkatkan substansi keamanannya dengan bersekutu jika yang lain abstain. Kedua, beberapa negara takut negara lain tidak abstain, dan bersekutu untuk menghindari isolasi atau untuk menghindari partner yang bersekutu melawan mereka. Ketika aliansi terbentuk, pihak lain tidak dapat memastikan niat dibalik pembentukan 
Vol. 1 No. 2 (2018)

aliansi tersebut, sehingga akan diikuti dengan pembentukan aliansi lain sebagai kekuatan tandingan (Snyder, 1984). Ketika aliansi sudah terbentuk, dalam fase kedua pertanyaannya tidak lagi apakah akan membentuk aliansi atau tidak, tetapi menjadi seberapa jauh komitmen yang akan diberikan kepada partnernya, dan seberapa banyak dukungan yang akan diberikan kepada partner tersebut.

Fase kedua dari alliance game inilah yang selanjutnya disebut dengan dilemma aliansi. Dilema aliansi adalah situasi sulit dimana sebuah negara yang berada dalam aliansi harus menentukan pilihan antara dua kemungkinan yang sama-sama membingungkan. Terdapat faktor-faktor yang menentukan pilihan negara dalam dilema aliansi. Terutama adalah adanya ketergantungan (dependence) terhadap aliansinya, seberapa besar mereka membutuhkan bantuan satu sama lain dan persepsi mereka terhadap ketergantungan masingmasing. Terdapat beberapa bagian dari ketergantungan ini. Pertama, kebutuhan negara akan bantuan sekutunya ketika berperang karena kemampuan militer mereka yang lebih lemah dibandingkan musuh. Kedua, kemampuan aliansinya dalam menyediakan bantuan (semakin besar kekuatan mitra aliansinya, negara akan semakin bergantung kepada aliansi tersebut, hingga mereka menggabungkan kekuatannya untuk memperoleh keamanan yang cukup). Ketiga, tingkat ketegangan dan konflik dengan musuh (semakin besar tingkat ketegangan dan konflik, maka semakin besar kemungkinan mitra aliansi tersebut meminta bantuan). Keempat, alternatif yang dimiliki negara untuk beraliansi kembali (semakin banyak alternatif negara untuk melakukan aliansi, maka negara tersebut kurang bergantung dengan aliansinya saat ini). Berdasarkan ke-empat faktor dalam dilemma aliansi tersebut terdapat dampak yang bisa terjadi pada negara yaitu negara merasa takut ditinggalkan "abandonment" atau terjerat "entraptment”. Semakin kuat komitmen sebuah negara terhadap aliansinya, maka semakin besar resiko negara tersebut untuk terjerat dalam konflik yang melibatkan aliansinya tersebut terjerat (entraptment). Namun, jika sebuah negara memberikan komitmen yang samar dan lemah terhadap aliansinya, maka negara tersebut dapat terkena resiko ditinggalkan (abandonment). Semakin besar atau kecilnya tingkat ketergantungan suatu negara terhadap sekutunya, maka keuntungan maupun resiko ditinggalkan akan lebih dominan daripada keuntungan maupun resiko terjerat. Sehingga, suatu negara akan lebih takut akan ditinggalkan (abandonment) daripada terjerat (entraptment) jika merasa memiliki ketergantungan yang tinggi (secara langsung maupun tidak langsung), dan / atau dalam kondisi dimana mitra aliansi dianggap kurang bergantung (less dependent), komitmen yang tidak jelas dalam aliansi, serta adanya perilaku mitra aliansi yang kurang patuh.

Pada akhirnya, negara akan memilih untuk bekerja sama (cooperate) atau membelot (defect). Untuk mengurangi resiko ditinggalkan oleh aliansinya, negara akan cenderung mengambil strategi kerja sama (cooperate) dengan menunjukkan komitmen yang kuat terhadap aliansi, 
mendukung aliansi dalam konflik dengan musuh, serta menghindari kedekatan dengan pihak musuh. Sebaliknya, negara akan cenderung memilik strategi membelot (defect) untuk menghindari resiko terjerat (entraptment) dalam konflik yang dihadapi musuhnya (Snyder, 1984).

Untuk dapat melakukan penelitian ini, penulis menggunakan metode kualitatif. Teknik pengumpulan data di lakukan dengan studi pustaka dan penelusuran berita, khususnya dari media daring. Setelah data berhasil dikumpulkan, penulis melakukan triangulasi data agar data yang diperoleh valid dan reliabel digunakan sebagai dasar dalam analisa. Triangulasi data dilakukan dengan cara mencocokkan data yang didapatkan dengan pertanyaan penelitian di dalam penelitian.

\section{Hasil dan Pembahasan}

\section{A. Ketergantungan militer Amerika Serikat yang rendah terhadap Jepang}

Menurut Snyder, ketergantungan merupakan faktor utama dalam menentukan pilihan suatu negara untuk bekerja sama atau membelot. Salah satu bentuk ketergantungan itu adalah kebutuhan negara terhadap mitra aliansinya ketika berperang karena kemampuan militer mereka yang lebih lemah dibandingkan musuh. Untuk dapat menentukan tingkat ketergantungan militer Amerika Serikat terhadap Jepang, perlu dilihat bagaimana kekuatan militer yang dimiliki oleh kedua negara tersebut.

Amerika Serikat merupakan salah satu negara yang memiliki sistem pertahanan yang sangat kuat dan canggih di dunia. Anggaran pertahanan Amerika Serikat juga menduduki peringkat nomor satu di dunia dengan 610 milyar USD (Brown, 2018). Selain kekuatan nuklirnya yang mumpuni, Amerika Serikat memiliki lebih dari 2 juta personil militer, 13.362 pesawat termasuk didalamnya terdapat pesawat tempur, 5.884 tank tempur, 415 aset laut yang didalamnya terdapat 65 kapal penghancur dan 66 kapal selam (Global Fire Power, 2018). Tidak hanya kuantitas dari kekuatan militer AS yang besar, kualitas senjata militer AS juga sangat canggih seperti pesawat tempur Lockheed Martin F-22 Raptor yang menggunakan teknologi siluman. Kekuatan militer Amerika Serikat juga tersebar di seluruh penjuru dunia. Pada tahun 2015, AS tercatat memiliki 686 pangkalan militer di luar 50 negara bagian AS, termasuk Jepang (Matanasi, 2016). Hal ini lah yang membuat Amerika Serikat menjadi kekuatan militer nomor satu di dunia.

Saat ini Jepang memiliki 310.457 personil militer, 1.500 pesawat militer, 679 tank tempur, 131 aset laut dimana dalam jumlah itu terdapat 36 kapal penghancur dan 17 kapal selam (Global Fire Power, 2018). Meskipun terdapat peningkatan dalam sistem pertahanan Jepang, dilihat dari perbandingan kekuatan militer Amerika Serikat dengan Jepang berdasarkan data tersebut Amerika Serikat masih jauh lebih unggul daripada Jepang. Oleh karena itu, tingkat ketergantungan Amerika Serikat terhadap Jepang dapat dikatakan rendah. 
Vol. 1 No. 2 (2018)

\section{B. Kemampuan Jepang dalam memberikan bantuan}

Faktor ketergantungan yang kedua menurut Snyder adalah kemampuan mitra aliansi dalam menyediakan bantuan. Dimana semakin besar kekuatan mitra aliansinya, negara akan semakin bergantung kepada aliansi tersebut, hingga mereka menggabungkan kekuatannya untuk memperoleh keamanan yang cukup. Konstitusi Jepang telah melarang Jepang menggunakan formasi militer secara tradisional. Jepang hanya memiliki Self Defense Force (SDF) yang hanya dapat melindungi negaranya sendiri. Dengan keterbatasan ini, SDF telah melakukan kegiatan yang bersifat kemiliteran dan peran logistik untuk membantu tentara Amerika Serikat di Jepang yang memiliki tujuan untuk melindungi Jepang. Sejak 9/11. SDF juga telah membantu ke beberapa negara seperti Afghanistan dan Iraq (Teslik, 2006).

Melihat kembali pada kekuatan militer kedua negara, kekuatan militer Jepang masih jauh dibawah Amerika Serikat. Dapat dikatakan bahwa hal ini tidak berlaku bagi Amerika Serikat karena sebaliknya, Amerika Serikat lah yang banyak membantu Jepang dalam mempertahankan keamanan Jepang. Walaupun Jepang juga memiliki sistem pertahanannya sendiri, Jepang masih memiliki kemampuan yang terbatas dalam melindungi negaranya, sehingga Jepang tidak banyak memberikan bantuan kepada Amerika Serikat.

\section{Tingkat ketegangan dan konflik dengan musuh}

Bagian ketiga dalam faktor ketergantungan dalam dilema aliansi adalah tingkat ketegangan dan konflik dengan musuh. Dalam hal ini, semakin besar tingkat ketegangan dan konflik dengan musuh, maka semakin tinggi tingkat ketergantungan dan keterlibatan suatu negara dengan mitra aliansinya tersebut. Jepang merupakan negara di Asia Timur yang secara geografis dekat dengan negara-negara yang memiliki sistem pertahanan yang cukup kuat sehingga rentan terlibat konflik dengan negara-negara disekitarnya seperti Korea Utara dan Tiongkok.

Korea Utara dan Tiongkok merupakan dua negara yang terus melakukan perkembangan dalam sistem pertahanannya. Saat ini, Korea Utara memiliki lebih dari 6 juta personil militer, 944 pesawat militer termasuk didalamnya 458 pesawat tempur, 5243 tank tempur, dan 86 kapal selam (Global Fire POwer, 2018). Selain itu, Korea Utara juga memiliki senjata nuklir yang siap diluncurkan. Sejak tahun 2006, Korea Utara sudah memulai melakukan uji coba rudal. Hal ini merupakan ancaman bagi negara-negara lain termasuk Jepang yang secara geografis masih berdekatan. Dalam uji cobanya, Korea Utara meluncurkan Hwasong-14 yang meluncur selama sekitar 45 menit sebelum mendarat di Laut Jepang yang juga menjadi salah satu ancaman bagi Amerika Serikat (Agiesta, 2018).

Ancaman lain bagi Jepang selain Korea Utara adalah Tiongkok. Tiongkok merupakan salah satu negara dengan system pertahanan militer yang cukup 
Vol. 1 No. 2 (2018)

kuat. Anggaran militer Tiongkok pada tahun 2017 menduduki peringkat kedua dibawah Amerika Serikat dengan 228 Milyar USD. Seiring dengan pertumbuhan ekonomi Tiongkok, Tiongkok juga terus melakukan modernisasi militernya. Tiongkok memiliki lebih dari 2 juta personil militer aktif, 1.125 pesawat tempur, 7.716 tank tempur, dan 73 kapal selam (Global Fire Power, 2018). Kekuatan militer Tiongkok meningkat drastic, ditambah lagi adanya latihan militer dan kerja sama militer dengan Rusia yang membuat Tiongkok menjadi sebuah negara yang patut disegani.

Selain sistem pertahanan Tiongkok yang kuat, Jepang dan Tiongkok terlibat dalam konflik perebutan Kepulauan Senkaku yang sampai saat ini masih berlangsung. Sudah banyak peristiwa yang menggambarkan ketegangan hubungan antara Tiongkok dengan Jepang. Pundak ketegangan konflik tersebut pada tahun 2012 saat Jepang menasionalisasi kepulauan tersebut dengan membeli Pulau Senkaku dari pemilik swasta Jepang. Kejadian itulah yang membuat hubungan Jepang dan Tiongkok semakin memanas. Berdasarkan dua ancaman tersebut, dapat disimpulkan bahwa tingkat ketegangan dan konflik Jepang dengan musuh cukup tinggi sehingga Jepang cenderung bergantung pada mitra aliansinya untuk membantu Jepang.

\section{Alternatif yang dimiliki Amerika Serikat untuk beraliansi}

Faktor terakhir yang menentukan ketergantungan sebuah negara adalah alternatif yang dimiliki negara untuk beraliansi kembali. Ketika negara memiliki pilihan aliansi dengan negara lain maka negara tersebut kurang bergantung pada aliansi yang saat ini mereka miliki. Sebagai negara great power, Amerika Serikat memiliki banyak hubungan aliansi seperti dengan Inggris, Kanada, Perancis, Australia, dan negara lainnya di Asia Tenggara. Selain beraliansi dengan Jepang, Amerika Serikat juga memiliki hubungan aliansi yang kuat dengan Korea Selatan. Selain kerja sama ekonomi, Amerika Serikat dan Korea Selatan juga melakukan aliansi pertahanan bersama dan bantuan militer lainnya. Aliansi pertahanan Amerika Serikat dan Korea Selatan dibentuk sebagai respon terhadap kebutuhan keamanan di Semenanjung Korea. Dibawah Perjanjian Mutual Defense 1953 Amerika Serikat dan Korea Selatan adalah sekutu. Pada tahun 2017, Amerika Serikat dan Korea Selatan menggelar latihan militer bersama. Latihan angkatan udara Vigilant Ace melibatkan 230 pesawat, termasuk jet tempur siluman F22 Raptor (CNN Indonesia, 2017). Hal ini memperlihatkan bahwa Amerika Serikat memiliki alternatif lain untuk beraliansi selain dengan Jepang. Berbeda dengan Jepang yang sistem pertahanannya sangat bergantung pada Amerika Serikat, Korea Selatan memiliki sistem pertahanan yang juga canggih seperti kapal selam buatan Korea Selatan.

Dari keempat faktor ketergantungan tersebut, pada faktor pertama dan kedua Amerika Serikat tidak bergantung pada Jepang. Hal ini ditunjukan dari kekuatan militer Amerika Serikat yang jauh lebih kuat daripada Jepang. Pada faktor ketiga, tingkat ketegangan dan konflik dengan 
Vol. 1 No. 2 (2018)

musuh cukup tinggi sehingga Amerika Serikat dapat terjebak dalam hubungan aliansi ini. Dari faktor keempat, Amerika Serikat masih memiliki alternatif untuk melakukan aliansi. Berdasarkan empat faktor ketergantungan Amerika Serikat terhadap Jepang, dengan menggunakan analisa dilema aliansi Amerika Serikat lebih merasa tidak ingin terjebak (entrapped) dalam aliansinya dengan Jepang. Menurut Snyder, apabila sebuah negara tidak ingin terjebak dalam aliansi, maka negara akan membelot (defect) terhadap mitra aliansinya. Contohnya adalah kebijakan Presiden Trump "America First" menimbulkan persepsi terhadap isolasi Amerika Serikat dari urusan global dan meninggalkan urusanurusan di Asia Timur (Singh, 2017). Pada kasus sengketa Pulau Senkaku, Amerika Serikat juga tidak melakukan hal-hal yang signifikan dalam membela Jepang. Padahal dalam perjanjian terdahulu, Amerika Serikat berkewajiban memberikan perlindungan terhadap Jepang. Dengan perilaku Amerika Serikat yang meningkatkan sistem pertahanan Jepang membuktikan bahwa Amerika Serikat ingin membiarkan Jepang untuk dapat melindungi dirinya sendiri dan tidak membuat Amerika Serikat terjebak

\section{DAFTAR PUSTAKA}

Agiesta, F. S. (2018, Maret 24). Inilah Senjata Nuklir Korea Utara yang bikin AS Gemetar. Dipetik Mei 27, 2018, dari Merdeka: https://www.merdeka.com/dunia/ini lah-senjata-nuklir-korea-utara-yangbikin-as-gemetar.html

Ando, S. (2013). Empirical Analysis of the Defense Interdependence dalam hubungan aliansi dan konflikkonflik yang tidak diperlukan bagi Amerika Serikat.

\section{Kesimpulan}

Berdasarkan uraian diatas, tulisan ini menunjukan bahwa tindakan Amerika Serikat dapat dilihat sebagai indikator untuk menunjukkan kecenderungan sikap Amerika Serikat yang membelot (defect) terhadap aliansinya dengan Jepang. Meskipun dalam bentuk peningkatan kerja sama militer, komitmen Amerika Serikat untuk menjadi "payung" pertahanan Jepang menjadi lemah. Hal ini dilakukan Amerika Serikat karena adanya ketakutan akan terjebak (entrapped) dalam konflik Jepang dengan musuhmusuhnya. Ketakutan tersebut muncul karena tingginya faktor konflik khususnya ketika Amerika Serikat harus terlibat konflik dengan Tiongkok maupun Korea Utara. Melalui peningkatan kekuatan militer Jepang, Jepang dapat mengurangi beban Amerika Serikat. Dengan demikian, hubungan dalam aliansi tersebut lebih menguntungkan bagi Amerika Serikat karena telah mengurangi resiko entraptment bagi Amerika Serikat.

Between Japan and the United States. Defense and Peace Economy , 223-231.

Chull, K. S. (2017). Endangering Alliance or Risking Proliferation?: US-Japan and US-Korea Nuclear Energy Cooperation Agreement. The Pacific Review , 692-702.

CNN Indonesia. (2017, Desember 3). ASKorsel Latihan Jet Tempur, Korut Ancam Perang Nuklir. Dipetik Mei 
27, 2018, dari CNN Indonesia: https://www.cnnindonesia.com/inte rnasional/20171203153336-113259826/as-korsel-latihan-jettempur-korut-ancam-perang-nuklir

CNN. (2007). Kapal Induk dan 14.000 Tentara AS Latihan Perang dengan Jepang. Dipetik Mei 10, 2018, dari $\mathrm{CNN}$ Indonesia: https://www.cnnindonesia.com/inte rnasional/20170809105314-113233446/as-dan-jepang-latihangabungan-di-dekat-semenanjungkorea,

Global Fire Power. (2018). China Military Strength. Dipetik Mei 27, 2018, dari Global Fire Power: https://www.merdeka.com/dunia/ini lah-senjata-nuklir-korea-utara-yangbikin-as-gemetar.html

Global Fire Power. (2018). Global Fire Power. Dipetik Mei 28, 2018, dari United States Military Strength: https://www.globalfirepower.com/c ountry-military-strength-

detail.asp?country_id=united-statesof-america

Global Fire Power. (2018). Japan Military Strength. Dipetik Mei 27, 2018, dari Global Fire Power: https://www.globalfirepower.com/c ountry-military-strengthdetail.asp?country_id=japan

Global Fire POwer. (2018). North Korea Military Strength. Dipetik Mei 27, 2018, dari Global Fire Power: https://www.globalfirepower.com/c ountry-military-strengthdetail.asp?country_id=north-korea

Hughes, C. W. (2007). Forging a Strengthened US Japan Alliance . Adelphi Papers , 97-115.
Ito, G. (2004). Leadership in Banwagon: A Historical Sketch of Japan's Security Policy. Policy and Society , 21-37.

Kelly, D. (2014). US Hegemony and the Origins of Japanese Nuclear Power:The Politics of Consent. Neww Political Economy, 819-846.

Kim, T. (2011). Why Alliances Entangle But Seldom Entrap States. Security Studies , 350-377.

Manthai, B. J. (2000). Alliance Theory, East Asia and The Japan-US Security Relationship. Western Ontario: University of Western Ontario.

Mathur, A. (2007). Japan's Changing Role in the US-Japan security alliance. Strategic Analysis , 503525.

Mearsheimer, J. (2001). Anarchy and The Struggle for Power. Contending Perspective, 54-72.

Menenberg, A. (2014). Collective Defense: Abe's New Security Plan. SAGE Publication, 68-72.

Muhaimin. (2017, November 17). Kapal Induk dan 14.000 Tentara AS Latihan Perang Dengan Jepang. Dipetik May 10, 2018, dari Sindonews:

https://international.sindonews.com /read/1258140/40/kapal-induk-dan14000-tentara-as-latihan-perangdengan-jepang-1510860427

Mulgan, A. G. (2010). Beyond SelfDefense? Evaluating Japan's Regional Security Role Under the New Defense Guidelines. Pacifica Review , 223-246.

Singh, B. (2017). Japan-ASEAN Relations: Challenges, Impact and 
Strategic Options. ASEAN at 50: A Look at Its External Relations , 95106.

Teslik, L. H. (2006, April 13). Japan and Its Military. Dipetik Mei 27, 2018, dari Council on Foreign Relations: https://www.cfr.org/backgrounder/j apan-and-its-military

Walt, S. M. (1985). Alliance Formation and the Balance of World Power. International Security, 3-43.

Wetson, S. A. (20014). The US-Japan Alliance in the New Post Cold War. Japanese Studies , 45-59.

Wirth, C. (2015). Securing Japan in the 'West': The US Japan Alliance and Identity Politics in the Asian Century. Geoppolitics , 287-307.

Wook, K. H. (2015). Substantiating the cohesion of the post-cold war USJapan alliance. Australian Journal of International Affairs , 287-307. 